\title{
A Typology of Reverse Innovation
}

Maximilian von Zedtwitz, Ph.D.

GLORAD - Center for Global R\&D Management and Reverse Innovation,

Chinese-German School for Postgraduate Studies (CDHK), Room 504,

Tongji University, 50 Chifeng Road, Shanghai, 200092 PR China

and

Skolkovo Institute of Science and Technology,

100 Novaya St., Skolkovo, Odintsovsky District, Moscow, 143025 Russia

Tel: +8613661917808 / Email: max@post.harvard.edu

Corresponding Author

\section{Simone Corsi, Ph.D.}

Institute of Management - Scuola Superiore Sant'Anna,

Piazza Martiri della Libertà, 2456127 Pisa, Italy

Tel.+39.050.883805 / Email: s.corsi@sssup.it

\section{Peder Veng Søberg, Ph.D.}

Center for Industrial Production, Department of Business and Management, Aalborg University,

Fibigerstrcede 10, 9220 Aalborg Ø, Denmark

Tel: +4599409348/+4551341155 /E-mail:pvs@business.aau.dk

\section{Romeo Frega}

MBA Candidate Class of 2014, Harvard Business School,

500 Soldiers Field Road, 02163, Boston, United States

Email:rfrega@mba2014.hbs.edu

Running Title: A Typology of Reverse Innovation 


\section{A Typology of Reverse Innovation}

Max von Zedtwitz is director of GLORAD, the Research Center for Global R\&D Management and Reverse Innovation, with offices at Skolkovo Institute of Science and Technology, Tongji University and the University of St. Gallen, and a professor of strategy and innovation. His research focuses on global $R \& D$ and innovation.

Simone Corsi is a post-doc researcher at Scuola Superiore Sant'Anna, Pisa, Italy and research associate at the Institute of Management of the School and at GLORAD at Tongji University. His research focuses on foreign $R \& D$ investment in emerging economies and reverse innovation.

Peder Veng Søberg is a post-doc researcher at Center for Industrial Production at Aalborg University in Denmark. He is also a GLORAD research associate at Tongji University. His research focuses on foreign invested $R \& D$ in emerging markets and global operations.

Romeo Frega is a business and development economics consultant. He previously worked for the Policy and Strategy Division of the United Nations World Food Programme in Rome, Italy as well as for the Boston Consulting Group in Zurich. As a graduate student at the University of St. Gallen, he worked at GLORAD on global R\&D and reverse innovation. He is currently pursuing his MBA at the Harvard Business School. 


\section{A Typology of Reverse Innovation}

\section{Abstract}

Reverse innovation commonly refers to an innovation initially launched in a developing country and later introduced to an advanced country. Adopting a linear innovation model with the four sequential phases of concept ideation, product development, primary target market introduction, and subsequent secondary market introduction, this study expands the espoused definition of reverse innovation beyond its market-introduction focus with reversals in the flow of innovation in the ideation and product development phases. Recognizing that each phase can take place in different geographical locations, the article then introduces a typology of global innovation with sixteen different types of innovation flows between advanced and emerging countries, ten of which are reverse innovation flows. The latter are further differentiated into weak and strong reverse innovation, depending on the number of innovation phases taking place in an emerging country. This analytical framework allows recasting of current research at the intersection between innovation and international business. Of the ten reverse innovation flows, six are new and have not been covered in the literature to date. The study addresses questions of ethnocentrism and the continuity of the flow of innovation, and discusses possible extensions of the model with respect to the number of geographical categories and phases of innovation. Four research propositions highlight areas for future investigation, especially in the context of optimizing a firm's portfolio of global innovation competence and capability. The implications for management are concerned with internal and external resistance to reverse innovation. Most significantly, while greater recognition and power of innovation in formerly subordinate organizational units is inconvenient to some, the ability to leverage the potential of reverse innovation makes a firm more likely to succeed in global innovation overall. 


\section{Introduction}

The rise of developing countries as emerging markets has attracted management scholars to investigate their role in global research and development (R\&D) and innovation. Ever since Vernon (1966, 1979) proposed the product life cycle theory, industrially advanced countries have been the center and origin of global diffusion of innovation (Cantwell, 1995). According to this traditional view, new products and technologies are first developed and launched in advanced countries, and only later introduced and commercialized in less developed countries when they have become increasingly mature, out-of-date, and obsolete. The flow of innovation, from a market point of view as much as from a technological perspective, is thus from advanced to developing countries.

Recent examples of products first introduced in developing countries and only later in advanced countries have challenged this paradigm (Govindarajan and Trimble, 2012). Portable ultrasound machines developed in China and initially marketed there have been successfully introduced in Western markets. Natural ingredients used in India for hundreds of years have been synthesized in Western pharmaceutical laboratories and sold as FDA-approved medicines to consumers in the US and Europe. Nokia developed phones in its Beijing R\&D lab, targeting the Chinese market before eventually introducing and marketing them in Europe. The term "reverse innovation" has become popular in both academic and managerial discussions to describe innovations as emanating from developing rather than advanced countries, and has even been used (especially in managerial press) to represent developing country-targeted innovation by foreign multinationals that would otherwise have been considered a form of advanced product localization. Common to all of these usages is the implication that the developing country is at the center of innovation. Immelt, Govindarajan, and Trimble (2009), for instance, described reverse innovation as the opposite of the "glocalization" process, in which multinationals first make products at home for the home market and subsequently localize them to other, usually less sophisticated markets. Building on this idea, Govindarajan and Ramamurti (2011) characterized reverse innovation as the process in which an innovation is adopted first in poor (developing) countries before "trickling up" to advanced countries. 
The idea that innovation originates in other than advanced countries is not new: for instance, Brown and Hagel (2005) used the term "blowback innovation" to describe innovative solutions developed and adopted first in emerging markets, and Hart and Christensen (2002) applied the disruptive innovation framework to new products coming from developing countries. An important stream of international business and innovation research has focused on the role and evolution of foreign subsidiaries of multinational companies (MNC) and their strategic contributions back to the parent organization (e.g., Birkinshaw and Hood, 2001). Subsidiaries located in emerging countries, despite their growing technology, production, and market capabilities (Zeng and Williamson, 2007), have received only limited attention (Zhang and Pearce, 2010). The role of local actors in global R\&D and innovation, especially domestic firms in developing countries, is an emerging focus of academic research and managerial practice (Luo and Tung, 2007; Li and Kozhikode, 2009). As many of these emerging market MNCs are becoming global players, one can assume that they actively pursue indigenous innovation and transformation of global technology.

While the central idea of reverse innovation is intuitively clear, it is conceptually vague. It is difficult to distinguish reverse innovation from other notions of innovation, such as cost innovation, Gandhian innovation, Jugaad work-around innovation, frugal innovation, and indigenous innovation (see Table 1). A reference framework for reverse innovation is still missing, especially one that integrates the various aspects of the ongoing research on international business and innovation. The most authoritative and fundamentally market-oriented definitions (Immelt et al., 2009; Govindarajan and Ramamurti, 2011; Govindarajan and Trimble, 2012) state that an innovation is reverse when it is first adopted in a developing country and only later in an advanced one; they either ignore the concept and development phases of innovation or, as in the case of Govindarajan and Ramamurti (2011), exclude them from their research focus. Arguing that market-oriented definitions are incomplete because they do not include the loci of idea generation and development as determinants of reverse innovation, we extend and refine them by defining reverse innovation as any type of global innovation that, at some stage, is characterized by a reversal of the flow of innovation from a developing to an advanced country, as long as this innovation is eventually introduced to an advanced country's mar- 
ket. Incorporating the phases of idea generation and development into the definition of reverse innovation makes it easier to understand the phenomenon for two reasons. First, it is in conceptual alignment with product life cycle theory, which also recognizes these early innovation phases, and therefore connects better with ongoing research on global innovation. Second, it reflects better the increasing commitment of developing countries to technological advancement, and their resulting capability and control of innovation.

--- Table 1 about here ---

The main conceptual goal of this article is to propose a comprehensive global innovation model that emphasizes the spatial patterns of innovation flow. Based on the linear model of the innovation process (e.g., Godin, 2006), it clarifies and expands the notion of reverse innovation beyond a purely market-introduction concept by identifying two additional reversals in the flow of innovation: development-based and ideation-based reverse innovation. Finally, this new notion of reverse innovation uses a simple bi-modal geographic distinction to create a framework that allows a more nuanced interpretation of global innovation flows involving developing countries.

The article also presents empirical evidence to balance the view that innovation is a prerogative of advanced countries and, more importantly, to dispel the notion that the flow of innovation is unidirectional, moving only from advanced to developing countries. The very term "reverse" innovation, however, still suggests a somewhat ethnocentric perspective regarding the expected flow of innovation. The proposed global innovation model is symmetrical and more impartial to the locus of innovation and its protagonists.

\section{The Shifting Locus of Innovation}

\section{Vernon Revisited in Light of the Rise of Emerging Markets}

Vernon's product life cycle hypothesis posits that factor conditions in advanced countries trigger innovation of new products aimed at the needs of local customers; the location of these innovation 
activities is in advanced countries not only because the entrepreneur has access to scientific knowledge and technology, but also because he has a greater likelihood and incentive to apply this knowledge, as he is geographically co-located with potential consumers (Vernon, 1966). Production initially takes place in the home country and eventually in other advanced countries. Sales and manufacturing migrate to less developed countries only after labor costs have become a differentiating factor, usually at the end of the product life cycle. With the rise of strong domestic firms targeting their home markets in Europe and Japan, Vernon (1979) revised his original model with the notion that the (advanced) home market may not be the only initial target market, although even this new model still portrayed developing countries as recipients of products only at the end of their life cycles or perhaps orchestrators of their own product life cycle targeting even less developed countries.

Bartlett and Ghoshal (1990) were among the first to report how innovations developed by local subsidiaries initially targeting local markets were often subsequently commercialized globally. Analyzing US patents, Cantwell (1995) revised Vernon's product life cycle model further by showing that the home country of a company is no longer the only and most probable location in which innovation occurs; the product life cycle may start in any advanced country leading the given technological discipline. The actual development of an original idea into a product and its manufacturing is now located wherever a company has a center of advanced know-how and production. These trends and their underlying drivers have been well documented and explained by scholars in a number of supporting disciplines, for instance Hedlund (1986), Ghoshal and Nohria (1989), and Gupta and Govindarajan (1991) for organizational structure, Håkanson and Nobel (1993) and Chiesa (2000) for international R\&D, and Frost (2001) and Frost and Zhou (2005) for geographic sources of innovation. Research on reverse knowledge and technology transfer (Buckley, Clegg, and Tan, 2003), defined as the transfer of knowledge or technology from a subsidiary to its headquarters, has given us insights on the importance of the level of national development (Ambos, Ambos, and Schlegelmilch, 2006), the role of the subsidiary (Frost, Birkinshaw, and Ensign, 2002; Mudambi, Mudambi, and Navarra, 2007; Phene and Almeida, 2008), technology characteristics (Håkanson and Nobel, 2000), and combinations of these factors (Frost, 2001; Almeida and Phene, 2004). Research on the flow of 
knowledge in innovation has been extensive, starting with Allen's (1977) and Katz and Allen's (1982) investigations of communication and knowledge sharing in R\&D. The international dimension of knowledge flows in innovation was added by Ghoshal and Bartlett (1988) and Gupta and Govindarajan (1991), and extended by Kuemmerle (1997) and Subramaniam and Venkatraman (2001). Hakanson and Nobel (2000), Buckley et al. (2003), and Ambos et al. (2006) have addressed the reversal of such flows.

This research has refined our understanding of how and why MNCs conceive, develop, and introduce new products. Although the role of local MNC subsidiaries and local host country factor conditions has been accentuated, the majority of global innovation research is focused on MNCs from advanced countries moving value-adding activities to other advanced and, more frequently now, to developing countries, thus reinforcing Vernon's product life cycle model.

Reverse innovation, however, addressed by few studies so far and mainly in the form of anecdotes, suggests a more radical departure from the role emerging markets have traditionally played in global innovation. Since Vernon's original thesis, developing countries ${ }^{1}$ have moved center stage for many MNCs as important markets to serve. Between 1960 and 2009, the share of developing countries in world GDP grew from 17\% to almost 40\% (Kose and Prasad, 2010). The cumulative gross domestic product (GDP) of the BRIC countries (Brazil, Russia, India, China) grew at a CAGR of $12.05 \%$ between 1990 and 2010, while the global triad countries (US, EU, Japan) grew at only 4.03\% (own analysis of UNCTADstat data). China and India have also attracted significant investment in foreign R\&D. More than 1,600 foreign R\&D centers have been reported in China by the PRC's Ministry of Commerce and several hundred foreign R\&D centers in India (Basant and Mani, 2012; Indian Ministry of Science and Technology, 2010). The trend toward R\&D in emerging markets has been documented since the turn of the millennium (UNCTAD, 2005; von Zedtwitz, 2006).

\footnotetext{
${ }^{1}$ Countries are classified as "advanced" or "developing" according to the International Monetary Fund (2012: 180-183). Authors sometimes use terms such as "advanced country," "developed country," and "industrialized economy" interchangeably, and "developing economy," "emerging country," or "developing nation," respectively. This article uses the term "emerging market" when referring to specific fast-growing markets in developing countries.
} 
Foreign $\mathrm{R} \& \mathrm{D}$ is gaining a foothold in developing countries, even though $\mathrm{R} \& \mathrm{D}$ in advanced countries still dominates the global innovation footprint (Dutta, 2011).

Tracking the locus of patenting is another measure used to quantify the shift of global innovation activity (Watanabe, Tsuji, and Griffy-Brown, 2001). While domestic patent applications in both advanced and developing countries have increased between 1985 and 2010, the relative weight between the two groups of countries has changed little (the ratio has remained at approximately $7: 3$ ), suggesting that global $R \& D$ activity has grown in proportion to existing $R \& D$ strength. Given the uniform international standards of the granting system, patents filed under the Patent Cooperation Treaty (PCT) are not subject to some of the national variations of recording patenting performance. In this domain, developing countries have more than doubled their share of global patent applications between 1985 and 2009. While their worldwide share is still relatively small at $8.03 \%,{ }^{2}$ developing countries realized a $19.86 \%$ annual growth rate compared to advanced countries which grew at only 13.69\%. According to 2013 WIPO data, China had become the fourth largest PCT filer in the world in 2012, behind Germany but ahead of Korea, France and the UK.

Still, developing country MNCs are gaining ground with respect to global R\&D. Own analysis of more than 7,300 R\&D locations of the 473 largest R\&D performing MNCs reveals that 79 are MNCs from developing countries, 63 of which had established 420 R\&D centers outside their home countries by the end of 2012. This includes well-researched firms such as Huawei with 29 R\&D centers in countries such as the US, Germany, the UK, India, Thailand, and Russia, but also lesser known firms such as Goodbaby, which has set up R\&D and design centers in Massachusetts, the Netherlands, Japan, and Hong Kong - in addition to having a sizeable R\&D organization in China, of course. Satyam, an Indian firm, has R\&D also in other developing or less developed countries such as Egypt, Brazil, and Malaysia (as well as in some advanced countries), and Sasol, a South African MNC, has global R\&D in Germany, the US, the UK, the Netherlands, and Italy. Many of these R\&D centers

\footnotetext{
${ }^{2}$ Data on patents presented in this article are obtained from the Worldbank Database for domestic patent applications, and from the World Intellectual Property Organization (WIPO) for Patent Cooperation Treaty (PCT) applications. Whenever possible, the data have been crosschecked with the patent offices of each country.
} 
may be small in comparison to their home bases, but they indicate the emergence of a global organization of R\&D that until recently was considered the hallmark of Western and Japanese MNCs.

\section{Framing Global Innovation Flows with Emerging Markets in Mind}

The current global landscape of R\&D and innovation (Dutta, 2011) is different from that of the 1960s, when Vernon formulated his product life cycle theory, and different from that of the 1970s and 1980s, when key typologies of global R\&D organization emerged.

First, companies no longer target their home country as their default primary market. MNCs from smaller countries have long abandoned this practice by aiming first at large advanced markets (Narula and Dunning, 2000; Buckley and Ghauri, 2004). Now, however, even MNCs from large advanced countries are targeting developing countries such as China if these markets have become more important than their home markets. As a consequence, international R\&D is not just about localizing products, but often involves developing products specifically for emerging markets as primary launch markets.

Second, product development and R\&D are not carried out exclusively in advanced countries but increasingly conducted directly in developing countries to benefit from local factor conditions and enhance innovation for local markets.

Third, products developed in and for developing countries occasionally prove superior to competing products elsewhere, including advanced home markets, and are subsequently being reintroduced in these home markets - again, a departure from Vernon's original premise.

Fourth, entrepreneurs and firms in developing countries not only develop but also conceive product ideas based on their own technologies and scientific insights. This is the last fundamental departure from Vernon's proposition that firms in advanced countries have preferential access to fundamental know-how, which gives them an edge in global competition and thus leads to innovation mostly in the (advanced) home country. 
These four departures from Vernon's premises regarding the global flow of innovation as captured in the product life cycle constitute the ingredients for what management practice and the literature call "reverse innovation."

\section{A Global Model of Reverse Innovation}

\section{Expanding the Notion of Reverse Innovation}

The debate on reverse innovation has so far focused on the introduction of innovations from a market point of view. Govindarajan and Ramamurti (2011: 191) define reverse innovation as "an innovation that is adopted first in a poor country before being adopted in rich countries," and Immelt et al. (2009: 56) explain that "it's the opposite of the glocalization approach that many industrial goods manufacturers based in rich countries have employed for decades." In this market introductionbased definition of the reversal of innovation, the authors accurately imply that an innovation can be new to the market without necessarily being new to the world, and that the perception of the customer determines whether an innovation is "reverse" in the sense of having been introduced in an emerging market first before being introduced in an advanced country later. The successful transition of an innovation from a primary target market in a developing country to a secondary market in an advanced country is a defining property of what the literature considers to be a reversal of the global flow of innovation.

Does the geographical origin of innovation matter? Thousands of R\&D and innovation centers established in developing countries over the past decade, many of which are owned and operated by MNCs from advanced countries, suggest it does (UNCTAD, 2005; Jaruzelski and Dehoff, 2008). This development-based definition of the reversal of innovation denotes a product or service developed in a developing country and, at a later point in time or immediately at product launch, introduced in an advanced country. It is during the development phase of an innovation that the core architecture of a product is implemented and key performance-defining features are added. In expanding the former understanding of reverse innovation with this development-based definition, we draw 
attention to the locus and contributions of innovators in developing countries in this crucial step in the value chain of a product, especially with regard to innovations that are the result of significant investments of time, risk, and capital in $R \& D$.

By introducing a development-based interpretation of reverse innovation, we emphasize the fact that innovation may flow across different locations. That such a flow should exist is not necessarily evident but firmly established in the literature (Rogers, 1962; Vernon, 1966 and 1979). In the simplest form, the concept of innovation flow means that the principal locus of the innovation shifts during the innovation process while the core idea of the innovation remains essentially unchanged. Although we know much about the benefits and challenges of separating R\&D and innovation activities (Allen, 1977; Gassmann and von Zedtwitz, 1999; Chiesa, 2000), our understanding of the specific factors causing such transitions into emerging markets is still developing (Li and Kozhikode, 2009; Christensen, Hang, Chai, and Subramanian, 2010). Dissemination of new products to usually non-colocated customers is a central economic tenet of commercial activity.

The early stages of the innovation process commonly comprise the two phases of idea/concept generation and product development. The first phase is often called "fuzzy front end" (Smith and Reinertsen, 1991) or "front end of innovation" (Koen et al., 2001) and includes the generation of one or more new ideas based on an opportunity or technology analysis (research) and the creation of a basic plan or concept for a product based on these ideas and on an existing stock of technical and customer knowledge. This early phase is characterized by tacit (Polanyi, 1967) and often sticky (von Hippel, 1994) knowledge, which makes spatial transfers costly and time intensive (Subramaniam and Venkatraman, 2001). Knowledge and know-how is less tacit in the subsequent development phase, which under suitable conditions can be codified and dispersed to take advantage of parallelization and capacity benefits (Gassmann and von Zedtwitz, 2003). This second phase is concerned with transforming the concept into a finalized product or service, and includes prototyping, system and module testing, performance tests, engineering, and industrialization of the new product (Cooper, 1994; Brown and Eisenhardt, 1995). 
In the context of global innovation, the ideation-based definition of reversal of innovation denotes the creation of the original idea or concept in a developing country and its subsequent transfer to an advanced country where this concept is implemented further. The critical element in this definition is the term "subsequent" because the time lag between ideation and development can be significant, and the two innovation phases would then, by most standards, not be considered part of the same flow of innovation. Nevertheless, the possibility of this form of reverse innovation exists and the potential for such developing country-originated innovations is real. Table 2 summarizes the three different definitions of reverse innovation along the flow of innovation.

--- Table 2 about here ---

\section{A Model of Global Innovation Flows}

Using the four innovation phases, that is, ideation, development, primary market introduction, and secondary market introduction, as temporal markers, as Vernon (1966) did previously, and utilizing the principal location of the innovation phase as a denominator by denoting advanced or developed countries with "A" and developing countries with "D," we arrive at a binary tree of 16 possible global flows of innovation. This 'map of global innovation flows' (see Figure 1, Table 3) also depicts reverse innovation as a subset of global innovation flows.

--- Figure 1 about here ---

--- Table 3 about here ---

We define as reverse innovation any type of global innovation that, at some stage during the innovation process, is characterized by a reversal of the flow of innovation from a developing country to an advanced country, and that is eventually introduced to an advanced country's market. Ideation/concept development, new product development, and first market introduction are key innovation phases; secondary market introduction is not. As a further refinement, we thus define reverse innovation in the strong sense as a reverse innovation that has at least two of its key innovation phases 
taking place in a developing country. This definition contrasts with a reverse innovation in the weak sense, which has only one of its key innovation phases taking place in a developing country. The following five types of reverse innovation flows are cases of reverse innovation in the strong sense (see also Table 4):

1. ADDA: Perhaps best described as a developing country spillover innovation, these products are conceived in advanced countries but developed and initially commercialized in developing countries, and then ultimately introduced in advanced countries. An example is Nokia's R\&D lab in Beijing using one of its most mature technology platforms to develop so-called "massmarket entry" phones for China and other emerging countries. Even though those mass-market entry terminals had targeted primarily lower price segment (such as "first-timer" terminals including only voice and short messaging), they were later reintroduced in advanced markets, where some of them became highly profitable blockbusters, one of them even the best-selling phone across Asia and Europe. Another example is the water purifier Lifestraw, ideated in Denmark and developed in Vietnam for emerging countries in Africa and Asia, but later also sold in advanced ones.

2. DADA: This category describes a class of reverse innovation with two reversals in the flow of innovation: the product is first conceptualized in developing countries, and then developed in advanced countries; it is commercialized first in developing countries, and later in advanced countries. For example, the Suzhou (China) subsidiary of Carel, an Italian mid-sized firm in the air-conditioning industry, used its local Chinese market and technology knowledge to conceive two new products initially targeted at Chinese customers: a room terminal for humidity and temperature control and an electronic controller for bottle coolers. These two products were developed at Carel's R\&D center in Italy. A more user-friendly configuration of the terminal was later introduced also in Europe. In the case of Carel's electronic controller, the customer - the Chinese subsidiary of a soft-drink producer-first successfully adopted it locally, and later expanded its use on a global basis, allowing energy savings of up to $50 \%$ compared 
to the other available solutions. Fiat 147, a flexible-fuel vehicle, was originally conceived in Brazil and developed in Italy in the 1970s for the Brazilian market and later adopted in other advanced markets.

3. DDAD: In this type of advanced country-targeted innovation, products are primarily developed for advanced markets before ultimately being reintroduced to developing countries, usually as part of a general globalization of the product. R\&D for SAP's Business One Suite, an enterprise resource planning system for small and medium-sized companies, is done by SAP Labs in China, targeting US and European customers first until the application becomes attractive also to its Chinese customers. US-based Dorel, which has many of its baby strollers designed, developed and manufactured by Goodbaby in China, also sells those eventually in Latin America.

4. DDAA: This is one of the more aggressive types of reverse innovation, in which a product is ideated and developed entirely in a developing country for the purpose of being marketed and sold solely in advanced countries. Often this flow occurs in innovations where the developing country-based innovator has unique know-how or a unique capability that he applies to an advanced country-based customer for local use, as for example in B-to-B relationships. Bosch's R\&D unit in Malaysia conceived and developed high-end impact screwdrivers that targeted Japan and subsequently European countries. Goodbaby designs and develops high-quality Maxi-Cosi baby strollers for sale in the United States and Europe.

5. DDDA: In this reversed product life cycle, innovations are developed and launched almost completely in developing countries first, and subsequently introduced in advanced countries. GE Healthcare's low-cost portable ultrasound machine developed in its China R\&D labs for the Chinese market (mainly focusing on rural clinics and lower level hospitals) was later successfully sold in the US market (see, e.g., Immelt et al., 2009) as a device for small clinics or ambulance services. P\&G created Vicks Honey Cough at its R\&D center in Caracas, Venezuela in 2003, with Mexico as its target market in mind, but in 2005 P\&G marketed the rebranded product also to Hispanic customers in California and Texas, and to markets in Western Europe 
the following year. Some of Huawei's China-developed mobile phones that were eventually introduced in the US are also in this category.

--- Table 4 about here ---

A reverse innovation in the weak sense has only one of the key innovation phases carried out in a developing country, but otherwise satisfies the condition of the reversal of the flow of innovation from a developing to an advanced country. The five global innovation flows that can be classified as weak reverse innovations are:

1. AADA: This describes a type of innovation that is created and developed in an advanced country specifically targeting an emerging market, and eventually spills back to an advanced country. De-featuring (a reduction of the number of product features) may be part of this innovation as long as it takes place during the product definition stage. In 1990, for instance, following its increasing presence in developing countries such as Brazil, China, Venezuela, Colombia, and Hungary, Parmalat developed a new milk packaging ("milk in a pouch") in order to accommodate lower purchasing power in those countries. The same packaging was later introduced in advanced countries (e.g., Canada) as an environmentally friendly solution. Grundfos in Denmark developed SQFlex, wind and solar-powered water pump with a backup battery system, especially for African and Asian markets, but later also introduced it in the US and Australia.

2. ADAA: Cost-saving factors or capacity constraints often persuade companies to move product development to a developing country even though the innovation targets markets in advanced countries only. It is not a case of reverse innovation if only subsidiary features or components are developed outside the home-based $R \& D$ centers, but if the majority of the R\&D effort is led by and carried out in a developing country before the product is commercialized in an advanced country, then a reversal of the traditional innovation flow has occurred. Much of the core design in STMicroelectronics's TV Set-Top boxes is still done in France but the main 
bulk of development is carried out in India, with their high-end boxes targeting advanced countries.

3. ADAD: This case is not unlike the ADAA innovation flow, but if the innovation is attractive enough to an emerging market customer, and mobile enough to be adopted without much adaptation, it is best described as a reverse spillover innovation. Siemens moving the development of its 'Advanced Multifunctional Operator Service System' from Munich to Bangalore for cost and capacity reasons is such an example. SAP Hana's in-memory apps ideated and marketed in Germany, but developed in China and India, often are sold in emerging markets as well. Vibram's minimal FiveFingers shoes also are in this category, originally created in Italy and then developed in China, they initially targeted the more mature markets in the USA and Europe, but they were later sold worldwide.

4. DAAA: Best called front-end reverse innovation because the reversal of the flow happens early, this type of innovation has its origins in a developing country but is completed and commercialized in an advanced country; it is barely distinguishable from more traditional types of innovation. If time lag did not matter at all, many historic Chinese and Indian inventions could be considered of this type. A modern example involves outsourcing of early-stage research to contract research organizations such as Wuxi AppTech. Based on targets specified by customers mainly located in the US and Europe, Wuxi AppTech develops technological solutions that help global drug and medical device manufacturers shorten lead times and lower R\&D cost. These qualified substances then become ingredients in global FDA-approved products.

5. DAAD: This developing country-inspired product life cycle is similar to the DAAA flow except that the innovation is ultimately introduced back to a developing country. For instance, in the 1950s Dr. J.G. Armstrong discovered remedial effects in Catharanthus roseus, or Madagascar Periwinkle, which was subsequently developed as Vincristine, and approved for cancer chemotherapy by the FDA in 1963. Eli Lilly sold it worldwide as Oncovin, first in the advanced world and later in Africa and other developing countries. 
The remaining six types of global innovation are cases of non-reverse innovation, i.e., they are not characterized by a reversal of the innovation flow in any of the key innovation phases, and they are not introduced in an advanced country market:

1. AAAA: This type is best described as an advanced country-only innovation without the involvement of a developing country at any stage. For instance, Bavarian Nordic's smallpox vaccine Imvamune is sold only in the US and Canada.

2. AAAD: This type is similar to AAAA, but with the additional characteristic that the advanced country-only innovation is introduced to a developing country at the end of its lifetime. This is the archetype of Vernon's product life cycle. Many manufacturing joint ventures (JV) in developing countries were started to extend the life of aging products, such as Volkswagen's Santana in China.

3. AADD: This is an innovation conceived and developed entirely in an advanced country but targeted exclusively at developing countries. For instance, Grundfos combined its Denmarkdeveloped SQFlex with Safaricom's M-Pesa payment system to create a cheap and clean water source, selling it as Lifelink first in Kenya and later other African countries.

4. ADDD: This flow type is best described as advanced country-inspired innovation. For example, French carmaker PSA generated a concept for a new luxurious car - the Metropolis whose design and development was later carried out in PSA's R\&D facilities in China, supported by a new local joint venture with Chang An Automotive Group. PSA's intent was to penetrate the Chinese market at its highest end-segment, leveraging on Chinese cultural peculiarities and habits and even customizing to domestic style variations. The Chinese firm Wanyan adopted foreign invented decoder technology to develop CDs carrying video data, thus pioneering a sizeable but mostly Southeast Asia-based VCD industry.

5. DADD: In this type, the original idea comes from a developing country, but development takes place in an advanced country before the result is marketed in a developing country. This innovation covers, for instance, country-specialized products with critical technology compo- 
nents that can be designed and developed only by R\&D laboratories in advanced countries. Examples are JAC's Tojoy, a car co-developed with Italy's Pininfarina, or Xechem International's sickle cell anemia-fighting Nicosan based on Nigerian traditional medicine.

6. DDDD: This type describes developing country-only innovation, without the involvement of an advanced country at any stage, not even as a potential market. An example is the Hippo Roller, a water transportation device designed in South Africa and currently being introduced to other African nations.

The resulting model is internally consistent inasmuch as it is logically complete, non-redundant, and non-contradictory. It is based on a distinction between advanced and developing countries, and while there is no unanimous definition for what constitutes membership in either of those country categories, it is a mutually distinct classification. It is also based on a relatively simple and hence widely applicable linear flow of innovation covering product ideation/concept development, product development, initial market launch, and subsequent secondary market introduction. The argument that the mapping of the flow of innovation in a linear pattern is overly simplistic will lead back to earlier discussions of the merit and deficiencies of linear models of innovation.

Consistent with earlier market-based definitions of reverse innovation, the model classifies innovations initially launched in an emerging market and later introduced in advanced countries as xxDA even if the innovation continued to be marketed in emerging markets, and analogously it uses XxAD for innovations initially launched in advanced country markets and only later introduced in emerging countries even if they were still available in their initial advanced country markets. xxAA and xxDD denote flows of innovations that stay in countries of their primary market classification.

This model was developed primarily with product innovation in mind, but it also applies to other kinds of innovation, such as technology innovation, business-model innovation, and process or service innovation. Using several innovation types simultaneously will test phase and boundary definitions within the linear model. However, the purpose of this typology was not to develop a grand unified model of all innovation types but rather to provide a map of global innovation flows that dis- 
cerns a subset of reverse innovation. Many of the terms for innovation flows in this model are based on recent predominant practice in global innovation, which may evolve over time and hence require relabeling. Although it is practically impossible to take stock of all global innovations, it is safe to assume that some flows are less frequent than others. Whether this is a consequence of managerial opportunity or conceptual oversight is a topic for future research.

\section{Discussion}

\section{Strengths and Merits of the Typology}

"Reverse innovation" is just one of many recent additions to the jungle of innovation terms that have come to be used in the context of developing countries and emerging markets. Concepts such as frugal innovation, cost innovation, innovation for the bottom of the pyramid, etc. (see Table 1) often have overlapping characteristics and create terminology confusion. Common to all of them is that they describe innovation in developing countries, from developing countries, and sometimes even for developing countries.

The proposed model provides clarity at least with respect to reverse innovation. Building on Rogers' (1962) concept of a flow of innovation and Vernon's (1966) four main phases of international innovation, it distinguishes between advanced and developing countries both as markets and creators of global innovation flows. The global innovation model has expanded the notion of reverse innovation beyond a reintroduction of products successful in developing countries to markets in advanced countries. Knowledge is created, codified, and embodied in new products and services before launch, and the model captures the innovative value added in developing economies (e.g., Christensen et al., 2010; Hang, Chen, and Subramanian, 2010). This model appears to be one of very few to explicitly differentiate along the geographical locus of innovation; most international models of innovation map a flow between headquarter and subsidiaries (e.g., Ghoshal and Bartlett, 1988). For instance, reverse innovation and reverse knowledge transfer differ also in the sense that reverse knowledge transfer is simply knowledge flow back to the headquarters (Buckley et al., 2003). Previous research 
has assumed that innovation activities are ideally co-located; even Vernon's hypothesis builds on the premise that the advanced country inventor is physically close to available technology, customers, and expressed needs. While the differentiation into only two location categories may be crude, it enables a clearer organization of future analysis along previously established patterns of research. Research that has emphasized the organizational locus of innovation - for example, offshoring, collaborative product development, reverse knowledge transfer, and outsourcing - can now be recast with potentially new insights.

The definition of a "reversed" vis-à-vis a "normal" flow of innovation might raise concerns of ethnocentrism. Innovation is not a new concept for developing countries, even though they may not have the industrial sophistication of high-tech innovation found in advanced countries, and their innovations are generally diffused only within geographically limited regions, in contrast to the international innovation flows from advanced countries. For this purpose the term "reverse" is no more than a tool for describing an empirical phenomenon seen against the current paradigm. Moreover, the reverse direction of the flow of innovation is not defined by any particular country (e.g., from a Chinese point of view, any innovation first launched somewhere else before it is launched in China could rightfully be considered a reverse innovation); it is the classification of the involved countries at the time of the flow that determines whether the innovation is reverse or not. For instance, a thousand years ago Europe's economy would have been classified as developing, whereas China's and the Middle East's would have been classified as advanced.

The model thus also challenges our understanding of temporal continuity in innovation. Even though the model seems to impose a strict sequential straightjacket on innovation, it does not designate how much time may elapse in each phase or, equally important, between two phases. How much delay can there be in a process of innovation before it is no longer identifiable as a flow? How long can the innovation process be suspended? Rogers (1962) puts no upper limit on the time innovation may take to disseminate to new adopters. Related questions to resolve in this context involve the definition of the origin of an innovation (an identifiable source of a new idea or technology) and the extent to which the innovation can be internalized. 
Finally, the new model also introduces six new innovation flows that have not yet been identified as reverse flows in the literature. On the basis of the earlier market-based definition, only $\mathrm{xxDA}$ flows (i.e., AADA, ADDA, DADA, and DDDA) have been recognized as reverse innovations. On the basis of the new model, six more innovation flows are reverse: ADAA, ADAD, DAAA, DAAD, DDAA, and DDAD. Two of these are reverse innovations in the strong sense.

\section{Weaknesses and Implications for Future Research}

While the relative simplicity of the model is useful for creating a cogent conceptual framework, the phases of an innovation flow may not always be as clearly delineated as the model would suggest, neither across time as part of a continuous flow nor across a multi-country geography. Any shortcomings of the model's applicability need to be addressed in future research.

With four distinct phases, the innovation flow is linear and gives the impression of being deterministic. The model, which follows the four generic phases of Vernon's product life cycle theory, could be expanded beyond primary and secondary markets (the final two innovation phases) toward tertiary markets, for instance when an innovation is first introduced in China as the home country, and next in other BRIC countries, before the company is sufficiently confident or resourceful to enter markets in advanced countries. Simultaneous market launches, especially those that immediately target both advanced and developing markets, also stretch the model.

The notion of flow could also be more refined for the earlier innovation phases, but this would not fundamentally change the sequential logic of concept and product creation. This issue is more pronounced in mixed-innovation use of the model. For instance, it is often difficult, and sometimes impossible, to separate product from technology development. Is the Tata Nano a DDDx or an ADDx innovation? The case for DDDx is that the product was conceived in India; the case for ADDx is that the automobile concept, on the basis of which the Tata Nano was later developed, was developed in the West. Drawing a clear boundary is also difficult when we have research-intensive products such as medicines (Oncovin, for example) where the first innovation phase is science rather than productfocused. If the model is used for technology innovation, then questions about transitioning ownership 
and temporal distance between phases are likely to arise; if the model is used for product innovation, these issues are less acute.

More research on innovation conducted concurrently in different countries is also necessary. This was hardly an issue during Vernon's time, but with the arrival of modern telecommunication and information technologies and more lateral business structures, innovation is increasingly performed simultaneously in multiple locations. Most new product development projects are still conducted in one location or in one country only (Li and Vanhaverbeke, 2009), and even when several countries are involved, the leadership and the lion's share of the work usually reside in one location. Still, there are always a few cases of innovation that are truly multinational in nature and that may be more difficult to map with the present simplified scheme. Given the multilateral collaboration in such innovation projects, we suspect they would not qualify as reverse innovations.

It may be worthwhile to note that an innovation can only be called reverse after a reversal of the flow has actually occurred. What exactly triggers those reversals, that is, the antecedents of reverse innovation, remains largely unexplored, and would require a reclassification of push and pull factors in global R\&D and innovation literature.

Another expansion of the model concerns the relatively simple distinction between "advanced" and "developing" economies. A more nuanced model could include fast-follower countries such as China, India, and Turkey, least-developed countries, which make up the majority of "markets at the bottom of the pyramid" (Prahalad, 2004), and newly industrialized countries. Such countries are aggregated in the model under the term "developing country"; future research should utilize the categorization scheme best suited to the chosen reference framework and intended application.

The model allows researchers to conceptualize, capture, and analyze areas of global innovation thus far neglected because of few actual observed innovation cases (e.g., a DADA flow of innovation) but of potentially important future application and theoretical interest. The model also seems to map a generational timeline from the top (AAAA) to the bottom (DDDD), implying that, historically, the majority of global innovation flows first took place in ways identified by Vernon (AAAA or AAAD) but gradually started to include flow types located immediately below, such as those that 
targeted developing countries as primary markets, as well as flow types emerging later, such as those that describe product development in developing countries. ${ }^{3}$

\section{Research Propositions}

While the majority of global innovation still seems to be of Vernon's original type, future innovation flows will likely be more evenly distributed among the types outlined here. As described earlier, there is a trend, driven in part by the global ascendency of MNCs from developing countries, in part by MNCs worldwide, and especially by advanced countries, to locate R\&D centers in developing countries while continuing to serve markets in their home countries. Thus:

Proposition 1: In the future, there will be more reverse innovation of both weak and strong types.

MNCs aim to leverage local advantages in global innovation, although these advantages may differ between advanced and developing countries. Reverse innovations in the strong sense are originating mostly from developing countries, according to the model, while weak reverse innovation originates from advanced countries. Six of the ten reverse innovation flows, and four of the five strong reverse innovation flows, have their earliest ideation stage in a developing country, and only one (weak) reverse innovation flow does not pass through a developing country in either concept development or new product development. Hence:

Proposition 2: Developing country MNCs will engage more in strong reverse innovation than will advanced country MNCs, and advanced country MNCs will engage more in weak reverse innovation.

Failing to leverage local home country advantages would be as damaging as failing to exploit market opportunities abroad. Several cases of reverse innovation reported in this article were motivated by the failure to successfully innovate the original technology along traditional global innovation flows. Competing firms who master the art of leveraging countries as sources of both know-how

\footnotetext{
${ }^{3}$ The authors are grateful to Rajneesh Narula for this important insight, based on his reading of an earlier version of this
} article. 
and markets, wherever they may be and at whatever level of development, will have an advantage over those firms that stagnate in their global innovation capability (Chen et al., 2012). Therefore:

Proposition 3: MNCs that engage in reverse innovation will improve their overall innovation productivity.

Access to host country advantages has been a strong driver for globalization of innovation (von Zedtwitz and Gassmann, 2002). Findley (1978) argues that countries with large development differences have a stronger need to catch up, while Cohen and Levinthal (1990) suggest that countries with low cognitive and institutional distance find it easier to do so. Intellectual property regimes are of particular importance in this context, as they have positive bearing on both foreign inbound direct investment and overall domestic innovative capacity and stock of knowledge, improving overall conditions for innovation in a country (D'Agostino and Santangelo, 2010). Thus:

Proposition 4: In the future, there will be more reverse innovation (both weak and strong) from developing countries with improved institutional frameworks.

\section{Managerial Implications}

Managers expect competitive advantage from reverse innovation, but they seem to struggle to implement and embrace it. As a subset of global innovation, reverse innovation inherits the managerial challenges characterizing distributed $R \& D$ and product development. There are also several important implications unique to the specific nature of reverse innovation such as individual people, departments, or organizations resenting the challenge to the status quo. This leads to resistance from headquarters and key R\&D departments when their authority to lead global innovation projects is undermined; resistance from engineers who distrust defeatured products to meet their high standards of technical sophistication; and resistance from customers and markets who are reluctant to adopt products pioneered outside their own advanced home countries because of perceived quality and reliability issues. 
These principal-agency issues, including not-invented-here resistance within central R\&D labs and the operational difficulties of overcoming inefficiencies in distributed R\&D work, are acerbated by ethnocentric behavior by people in firms not sufficiently experienced in working with emerging countries. Innovation flows from advanced to developing countries are much more accepted, and much more supported and expected, than flows in the reverse direction, even by customers and firms from developing countries. In line with Proposition 3, MNCs who are able to build innovation capability in emerging markets alongside localized innovation leadership are more likely to benefit more from reverse innovation. Improved ability of MNCs to engage in reverse innovation will undermine the ability of emerging market MNCs to leverage their own home-advantage in global competition. With their low-cost advantages eroding, MNCs from emerging markets find it increasingly difficult to break into advanced country markets unless they are able to build up overseas innovation capability themselves (Proposition 2). Not surprisingly, many emerging country MNCs have started to leverage their own relative innovation advantages with respect to markets in countries less developed than their own (South-South innovation flows).

At the level of the process of innovation, companies prefer to keep concept development and product development co-located. The advantage of implementing product development in a low-cost location is often more than counterbalanced by the costs of moving tacit knowledge around, or the inefficiencies of multi-site collaboration and coordination. AAxx and DDxx flows are easier than ADxx and DAxx innovations, unless innovation projects are typically decoupled at this interface anyway (e.g., in software or pharmaceuticals). As reverse innovation still appears to be the exception rather than the norm, it is too early to point to emerging best practice. However, firms who are able to integrate resources, capabilities and applications more dynamically than others are presumed to be more innovative overall (Teece et al, 1997).

MNCs that have their global innovation processes under control will also be able to pursue different reverse innovation flows simultaneously. One immediate consequence is their ability to concurrently target multiple markets with variations of the same product concept. Rather than adjusting products to developing countries later in their lifecycles, they are able to integrate product features 
early in the concept development phase to satisfy customer requirements from markets with different levels of maturity. These MNCs target products still at primary key markets, but they are able to introduce localized product variations more rapidly and with greater fit.

In many MNCs, global strategy still lags behind the reality of innovation in emerging markets. Those who claim to be "in China for China," or "in India for India" respectively, have progressed from the old paradigm of the headquarters-centered multinational, but they are still short of what Bartlett and Ghoshal (1988) called a "transnational" firm, one that innovates locally for global benefits. This requires radical updating of outdated strategies and processes in many MNCs.

Reverse innovation also has implications for innovation policy. For instance, inbound FDI is often supported because local spill-over effects are expected. But what if foreign R\&D centers engage in reverse innovation? Why should local policy makers subsidize foreign R\&D in their country if MNCs aim to use host-country innovations for the benefit of far-away markets? We would expect local policy to support local R\&D going into local products first (xDDx instead of $x D A x)$. In the same vein, policies in the home country of MNCs focus on keeping jobs at home, and hence policies in those countries will likely discourage shifting innovation capability offshore and thus weaken a firm's ability for reverse innovation overall.

In summary, only the most experienced MNCs are able to systematically benefit from reverse innovation. Others are occasionally lucky when both internal and external conditions for reverse innovation are serendipitously favorable. Most MNCs, however, now integrate expectations for reverse innovation into local mission statements and performance objectives. The proposed model should help innovation managers to prioritize among different types of reverse innovation and develop a roadmap of innovation targets that can be realistically achieved given the organizational maturity of the local subsidiary and R\&D organization. Using the more refined characterization of reverse innovation flows, MNCs are able to identify shortcomings in their present global innovation network and undertake the steps necessary to transform themselves-their people, their organization, and their processes-into more competent global innovators. 


\section{Conclusions}

Introducing a new conceptual link between innovation research and international business, this article outlined a reference framework of sixteen different types of global innovation flows between advanced and emerging countries. We expanded the definition of reverse innovation beyond a purely market-introduction concept by identifying two additional reversals in the flow of innovation: development-based reverse innovation and ideation-based reverse innovation. The different types of reverse innovation were described on the one hand by a four-phase innovation flow, and on the other hand by a binary distinction between advanced countries and emerging countries as the locus of the innovation activity. The model gave rise to a total of ten types of reverse innovation flows, six of which had not been identified as such in the literature. It aggregates two key structural dimensions, geography and time, while retaining analytical freedom over other dimensions that management research employs to study innovation. The resulting framework provides researchers with consistent terminology and an analytical model for studying global innovation and R\&D patterns in general and reverse innovation flows in particular.

\section{References}

Allen, T.J. 1977. Managing the flow of technology: Technology transfer and dissemination of technological information within the $R \& D$ organization. Cambridge: MIT Press.

Almeida, P., and A. Phene. 2004. Subsidiaries and knowledge creation: The influence of the MNC and host country on innovation. Strategic Management Journal 25 (8-9): 847-864.

Ambos, T. B., Ambos, and B.B. Schlegelmilch. 2006. Learning from foreign subsidiaries: An empirical investigation of headquarters' benefits from reverse knowledge transfers. International Business Review 15 (3): 294-312.

Bartlett, C.A., and S. Ghoshal. 1988. Organizing for Worldwide Effectiveness. The Transnational Solution. California Management Review 31 (1): 54-74. 
Bartlett, C.A., and S. Ghoshal. 1990. Managing innovation in the transnational corporation. In Managing the Global Firm, ed. C.A. Bartlett, Y. Doz, and G. Hedlund, 215-255. London: Routledge.

Basant, R., and S. Mani. 2012. Foreign R\&D centers in India: An analysis of their size, structure and implications. Working Paper No. 2012-01-06, Indian Inst. of Manage., Ahmedabad: India.

Birkinshaw, J., and N. Hood. 2001. Unleash innovation in foreign subsidiaries. Harvard Business Review 79 (3): 131-138

Brown, S.J., and J. Hagel III. 2005. Innovation blowback: Disruptive management practices from Asia. The McKinsey Quarterly 1: 34-45.

Brown, S.L., and K.M. Eisenhardt. 1995. Product development: past research, present findings, and future directions. Academy of Management Review 20 (2): 343-378.

Buckley, P.J., J. Clegg, and H. Tan. 2003. The art of knowledge transfer: Secondary and reverse transfer in China's telecommunications manufacturing industry. Management International Review 43 (2): 67-93.

Buckley, P.J., and P.N. Ghauri. 2004. Globalisation, economic geography and the strategy of multinational enterprises. Journal of International Business Studies 35 (2): 81-98.

Cantwell, J. 1995. The Globalisation of technology: What remains of the product cycle model? Cambridge Journal of Economics 19 (1): 155-174.

Chen, C.-J., Y.-F. Huang, and B.-W. Lin. 2012. How firms innovate through R\&D internationalization? An S-curve hypothesis. Research Policy 41 (9): 1544-1554.

Chiesa, V. 2000. Global R\&D project management and organization: A taxonomy. Journal of Product Innovation Management 17 (5): 142-359.

Chiesa, V., and F. Frattini. 2011. Commercializing technological innovation: Learning from failures in high-tech markets. Journal of Product Innovation Management 28 (4): 437-454.

Christensen, C.M. 1997. The innovator's dilemma: When new technologies cause great firms to fail. Cambridge: Harvard Business School Press. 
Christensen, C.M., C.-C. Hang, K.-H. Chai, and A.M. Subramanian. 2010. Managing innovation in emerging economies: An introduction to the special issue. IEEE Transactions on Engineering Management 57 (1): 4-8.

Chutani, S., J.R. Aalami, and A. Badshah. 2010. Technology at the margins: How IT meets the needs of emerging markets. Hoboken, NJ: Wiley.

Cohen, W.M., and D.A. Levinthal. 1990. Absorptive capacity - A new perspective on learning and innovation. Administrative Science Quarterly 35 (1): 128-152.

Cooper, R.G. 1994. Perspective: Third-generation new product processes. Journal of Product Innovation Management 11 (1): 3-14.

D’Agostino, L.M., and G.D. Santangelo. 2010. Do overseas R\&D laboratories in emerging markets contribute to home knowledge creation? An extension of the double diamond model. Management International Review 52 (2): 251-273.

Dutta, S. 2011 (ed.). The global innovation index: Accelerating growth and development. Fontainebleau: INSEAD.

Findlay, R. 1978. Relative backwardness, direct foreign investment, and the transfer of technology: A simple dynamic model. Quarterly Journal of Economics 92 (1): 1-16.

Frost, T.S. 2001. The geographic sources of foreign subsidiaries' innovations. Strategic Management Journal 22 (2): 101-123.

Frost, T.S., J.M. Birkinshaw, and P.C. Ensign. 2002. Centers of excellence in multinational corporations. Strategic Management Journal 23 (11): 997-1015.

Frost, T.S., and C. Zhou. 2005. R\&D co-practice and reverse knowledge integration in multinational firms. Journal of International Business Studies 36 (6): 676-687.

Gassmann, O., and M. von Zedtwitz. 2003. Trends and determinants of managing virtual R\&D teams. $R \& D$ Management 33 (3): 243-262.

Gassmann, O., and M. von Zedtwitz. 1999. New concepts and trends in international R\&D organization. Research Policy 28 (2-3): 231-250. 
Ghoshal, S., and C. Bartlett. 1988. Creation, adoption, and diffusion of innovations by subsidiaries of multinational corporations. Journal of International Business Studies 19 (3): 365-388.

Ghoshal, S., and N. Nohria. 1989. Internal differentiation within multinational corporations. Strategic Management Journal 10 (4): 323-337.

Godin, B. 2006. The linear model of innovation: The historical construction of an analytical framework. Science, Technology \& Human Values 31: 639-667.

Gottschalk, L.R. 1969. Understanding history: A primer of historical method. New York: Knopf.

Govindarajan, V., and R. Ramamurti. 2011. Reverse innovation, emerging markets, and global strategy. Global Strategy Journal 1 (3-4): 191-205.

Govindarajan, V., and C. Trimble. 2012. Reverse Innovation: create far from home, win everywhere. Boston: Harvard Business Review Press.

Gupta, A.K., and V. Govindarajan. 1991. Knowledge flows and the structure of control within multinational corporations. Academy of Management Review 16 (4): 768-792.

Håkanson, L., and R. Nobel. 1993. Determinants of foreign R\&D in Swedish multinationals. Research Policy 22 (5-6): 397-411.

Håkanson, L., and R. Nobel. 2000. Technology characteristics and reverse technology transfer. MIR: Management International Review 40 (1): 29-48.

Hang, C.-C, J. Chen, and A. Subramanian. 2010. Developing disruptive products for emerging economies: Lessons from Asian cases. Research Technology Management 53 (4): 21-26.

Hart, S.L., and C.M. Christensen. 2002. The great leap: Driving innovation from the base of the pyramid. MIT Sloan Management Review 44 (1): 51-56.

Hedlund, G. 1986. The hypermodern MNC - A heterarchy? Human Resource Management 25 (1): 9-35.

Immelt, J.R., V. Govindarajan, and C. Trimble. 2009. How GE is disrupting itself. Harvard Business Review 87 (10): 56-65.

Indian Ministry of Science and Technology. 2010. Directory of R\&D institutions. New Delhi: Government of India, Department of Science and Technology. Available at: www.dst.gov.in 
International Monetary Fund. 2012. World Economic Outlook. April. Washington, DC: IMF.

Jaruzelski, B., and K. Dehoff. 2008. Beyond borders: The global innovation 1000. Strategy+Business 52 (Winter): 52-69.

Katz, R., and T.J. Allen. 1982. Investigating the not invented here (NIH) syndrome: A look at the performance, tenure, and communication patterns of $50 \mathrm{R} \& \mathrm{D}$ project groups. $R \& D$ Management $12(1): 7-20$.

Koen, P., G. Ajamian, R. Burkart, A. Clamen, J. Davidson, R. D’Amore, C. Elkins, K. Herald, M. Incorvia, A. Johnson, R. Karol, R. Seibert, A. Slavejkov, and K. Wagner. 2001. Providing clarity and a common language to the "fuzzy front end." Research Technology Management 44 (2): 4655.

Kose, A.M., and E. Prasad. 2010. Emerging markets: Resilience and growth amid global turmoil. Washington, DC: Brookings.

Kuemmerle, W. 1997. Building effective R\&D capabilities abroad. Harvard Business Review 75 (2): $61-70$.

Lazonick, W. 2004. Indigenous innovation and economic development: Lessons from China's leap into the information age. Industry and Innovation 11 (4): 273-297.

Li, J., and R.K. Kozhikode. 2009. Developing new innovation models: Shifts in the innovation landscapes in emerging economies and implications for global R\&D management. Journal of International Management 15 (3): 328-339.

Li, Y., and W. Vanhaverbeke. 2009. The effects of inter-industry and country difference in supplier relationships in pioneering innovations. Technovation 29 (12): 843-858.

London, T., and S.L. Hart. 2004. Reinventing strategies for emerging markets: Beyond the transnational model. Journal of International Business Studies 35 (5): 350-370.

Lu, Q. 2000. China's leap into the information age: Innovation and organization in the computer industry. Oxford: Oxford University Press.

Luo, Y., and R.L. Tung. 2007. International expansion of emerging market enterprises: A springboard perspective. Journal of International Business Studies 38: 481-498. 
Mudambi, R., S.M. Mudambi, and P. Navarra. 2007. Global innovation in MNCs: The effects of subsidiary self-determination and teamwork. Journal of Product Innovation Management 24 (5): $442-455$.

Narula, R., and J. Dunning. 2000. Industrial development, globalisation and multinational enterprises: New realities for developing countries. Oxford Development Studies 28 (2): 141-167.

Peng, S.Z., Y.F. Xu, and Q.X. Lin. 2009. The great revolution of Shanzhai economy: The innovation comes from imitation. Taipei: Showwe Information Co., Ltd.

Phene, A., and P. Almeida. 2008. Innovation in multinational subsidiaries: The role of knowledge assimilation and subsidiary capabilities. Journal of International Business Studies 39: 901-919.

Polanyi, M. 1967. The tacit dimension. New York: Doubleday Anchor.

Prahalad, C.K. 2004. The fortune at the bottom of the pyramid: Eradicating poverty through profits. Upper Saddle River, NJ: Pearson Education.

Prahalad, C.K., and R.A. Mashelkar. 2010. Innovation's holy grail. Harvard Business Review 88 (78): $132-141$.

Ray, S., and P.K. Ray. 2011. Product innovation for the people's car in an emerging economy. Technovation 31 (5-6): 216-227.

Rogers, E.M. 1962. The diffusion of innovations. New York: Free Press.

Rowlinson, M. 2004. Historical analysis of company documents. In Essential guide to qualitative methods in organizational research, ed. C. Cassell, and G. Symon, 301-311. London: Sage.

Smith, P.G., and D.G. Reinertsen. 1991. Developing products in half the time. John Wiley \& Sons.

Subramaniam, M., and N. Venkatraman. 2001. Determinants of transnational new product development capability: Testing the influence of transferring and deploying tacit overseas knowledge. Strategic Management Journal 22 (4): 359-378.

Teece, D. J., G. Pisano, and A. Shuen. 1997. Dynamic Capabilities and Strategic Management. Strategic Management Journal 18 (7): 509-533. 
Tellis, G.J., A.B. Eisingerich, R.K. Chandy, and J.C. Prabhu. 2008. Competing for the future: Patterns in the global location of $R \& D$ center by the world's largest firms. Report 06, Institute for the Study of Business Markets, Pennsylvania State University.

UNCTAD. 2005. World investment report: Transnational corporations and the internationalization of $R \& D$. New York and Geneva: United Nations Publications.

Vernon, R. 1966. International investment and international trade in the product cycle. Quarterly Journal of Economics 80 (2): 190-207.

Vernon, R. 1979. The product cycle hypothesis in a new international environment. Oxford Bulletin of Economics and Statistics 41 (4): 255-267.

Von Hippel, E. 1994. "Sticky information" and the locus of problem solving: Implications for innovation. Management Science 40 (4): 429-439.

von Zedtwitz, M. 2006. International R\&D strategies of TNCs from developing countries: The case of China. In UNCTAD: Globalisation of $R \& D$ and developing countries: Proceedings of the expert meeting, 117-140. Geneva.

von Zedtwitz, M., and O. Gassmann. 2002. Market versus technology drive in R\&D internationalization: Four different patterns of managing research and development. Research Policy 31 (4): 569588.

Watanabe, C., Y.S. Tsuji, and C. Griffy-Brown. 2001. Patent statistics: Deciphering a "real" vs. a "pseudo" proxy of innovation. Technovation 21 (12): 783-790.

Zeng, M., and P.J. Williamson. 2007. Dragons at your door: How Chinese cost innovation is disrupting the rules of global competition. Boston, MA: Harvard Business School Press.

Zeschky, M., B. Widenmayer, and O. Gassmann. 2011. Frugal innovation in emerging markets. Research Technology Management 54 (4): 38-45.

Zhang, S., and R. Pearce. 2010. Sources of technology and the strategic role of MNE subsidiaries in China. Multinational Business Review 18 (3): 49-72. 


\section{Appendix 1: Notes on Methodology}

Although this article makes a primarily conceptual contribution, the authors collected empirical data for illustration and validation of managerial practice. Their focal observation entity was the flow of product innovation through space and time. They interviewed at least two representatives for each innovation, often substantially more. Interviews lasting from 30 to 40 minutes were conducted between 2009 and 2011, in person or by phone, with participants who were selected on the basis of innovation experience from a database of more than 800 global R\&D directors. In order to avoid an undue bias toward just one country, examples were gathered from as many countries as possible, going well beyond China and India, the usual suspects for reverse innovation. In order to validate the model as widely as possible, examples of innovations were collected from multiple industries.

The authors also triangulated their findings using multiple sources, backing up qualitative interview findings with extensive document research and company-internal information. Innovation flows were categorized and reviewed with interview sources. When too much time had passed to identify appropriate innovation representatives, they followed historical case analysis guidelines (Gottschalk, 1969; Rowlinson, 2004; Chiesa and Frattini, 2011). Additionally, a lexicographical search using selected keywords (e.g., "reverse innovation," "innovation from emerging economies") found 249 articles (and 398 pages) in LexisNexis Academic. An extra 2,039 articles and 3,463 pages were obtained from LexisNexis Academic using selected keywords combined with selected company names or product names identified in the previous two steps. The content of these data (resulting in 2,288 articles and 3,861 pages) was examined, analyzed, and eventually used as examples and support for the reverse innovation flows identified in our model. As a result, the proposed model was validated and populated, gathering corroborating evidence from both management theory and industrial practice that the phenomenon is not just a single-industry or temporary occurrence. 


\section{Acknowledgment}

We are grateful for the support provided by Sino-Danish Research Center (SDC) and the program "Sciences and Arts Fellowships China" promoted by the Italian Ministry of Education, University and Research for providing financial support to the project.

\section{Figures}

Figure 1. A map of global innovation flows with reverse innovations in the strong and weak sense.

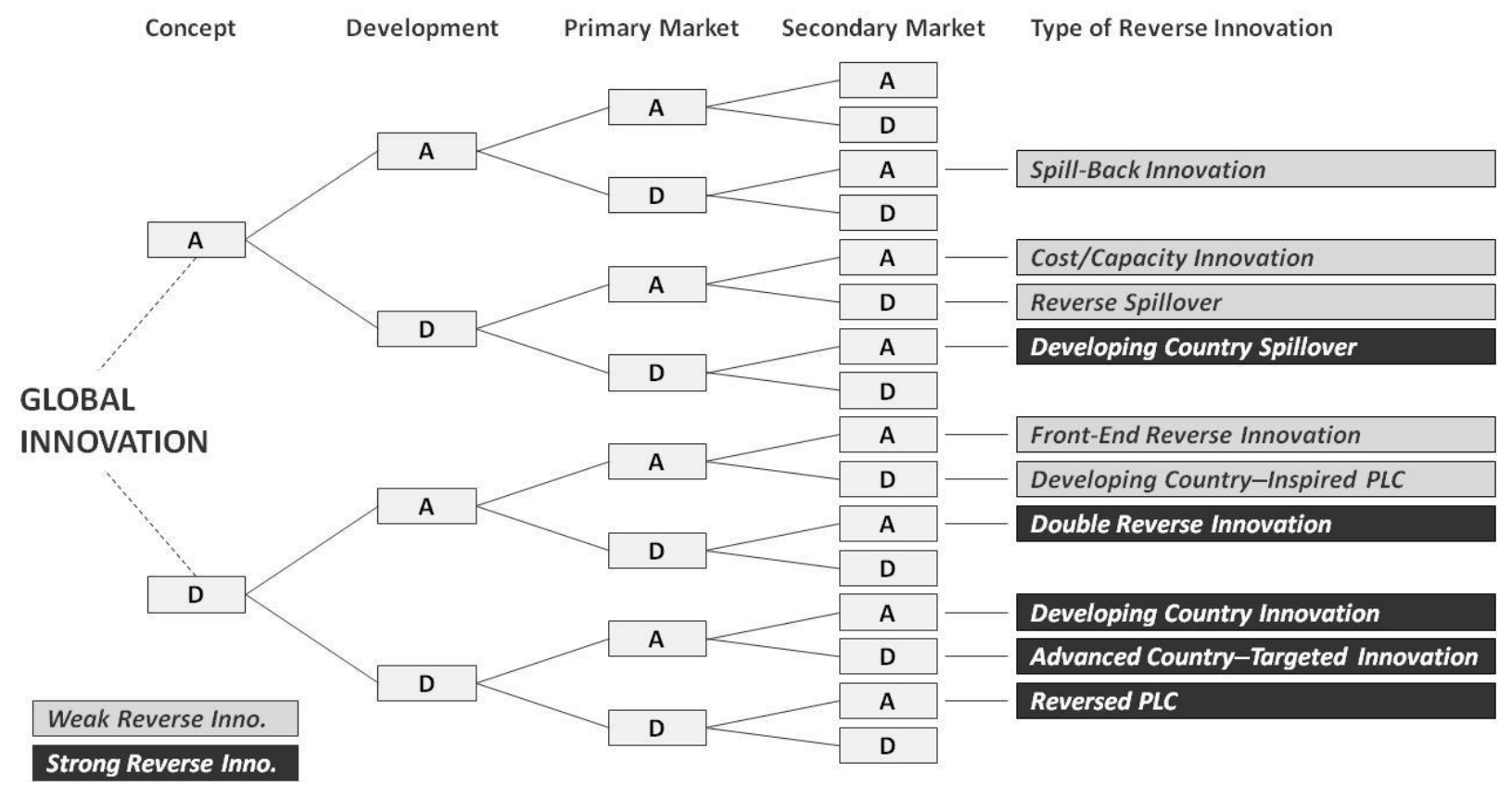




\section{Tables}

Table 1. Frequently used concepts of innovation for and from developing economies.

\begin{tabular}{|c|c|c|}
\hline $\begin{array}{l}\text { Type of Innovation for/from } \\
\text { Developing Economies }\end{array}$ & Definition & References \\
\hline Disruptive Innovation & $\begin{array}{l}\text { Affordable, "good enough" products that meet consumers' basic needs at } \\
\text { a relatively low cost }\end{array}$ & $\begin{array}{l}\text { Christensen (1997), Hart and Christensen } \\
\text { (2002), Hang et al. (2010) }\end{array}$ \\
\hline $\begin{array}{l}\text { Innovation at the Bottom of the } \\
\text { Pyramid }\end{array}$ & $\begin{array}{l}\text { Innovation developed in and targeting the large unserved segments of } \\
\text { poor people inhabiting emerging economies }\end{array}$ & Prahalad (2004), London and Hart (2004) \\
\hline Trickle-Up Innovation & $\begin{array}{l}\text { Innovations developed for the bottom of the pyramid that subsequently } \\
\text { trickle up to the developed world }\end{array}$ & Prahalad (2004) \\
\hline Indigenous Innovation & $\begin{array}{l}\text { A process of making use of technologies transferred from the advanced } \\
\text { economies to develop superior technologies at home }\end{array}$ & Lu (2000), Lazonick (2004) \\
\hline Blowback Innovation & Innovative solutions developed and adopted first in emerging markets & Brown and Hagel (2005) \\
\hline Cost Innovation & $\begin{array}{l}\text { Leveraging developing economies' cost advantage to develop innova- } \\
\text { tion at dramatically lower costs }\end{array}$ & Zeng and Williamson (2007) \\
\hline Reverse Innovation & $\begin{array}{l}\text { Innovations adopted first in poor (developing) countries before being } \\
\text { adopted in advanced economies }\end{array}$ & $\begin{array}{l}\text { Immelt et al. (2009), Govindarajan and } \\
\text { Ramamurti (2011), Govindarajan and } \\
\text { Trimble (2012) }\end{array}$ \\
\hline Shanzhai Innovation & Chinese low-quality, low-price imitations of foreign branded products & Peng, $\mathrm{Xu}$, and Lin (2009) \\
\hline Jugaad/Gandhian Innovation & $\begin{array}{l}\text { Innovations developed for the Indian market that responds to two Gan- } \\
\text { dhian tenets: affordability and sustainability }\end{array}$ & Prahalad and Mashelkar (2010) \\
\hline Frugal Innovation & $\begin{array}{l}\text { Innovation that has a large cost advantage, and in some cases inferior } \\
\text { performance, compared to existing solutions, and developed in a re- } \\
\text { source-constrained context }\end{array}$ & $\begin{array}{l}\text { Zeschky, Widenmayer, and Gassmann } \\
\text { (2011) }\end{array}$ \\
\hline $\begin{array}{l}\text { Resource-Constrained Innova- } \\
\text { tion }\end{array}$ & $\begin{array}{l}\text { Innovation developed in emerging economies in a context characterized } \\
\text { by lower power of purchase, lower understanding of technology, and } \\
\text { lower investment resources }\end{array}$ & Ray and Ray (2011) \\
\hline
\end{tabular}


Table 2. Three types of reversals in the global flow of innovation and associated reverse innovation.

\begin{tabular}{|c|c|c|c|}
\hline \multirow{2}{*}{ Innovation Activity } & \multicolumn{3}{|c|}{ Flow of Innovation: Ideation $\rightarrow$ Development $\rightarrow$ Market(s) } \\
\hline & Ideation & Development & Market Introduction \\
\hline $\begin{array}{l}\text { Prerequisite for a } \\
\text { Reverse Innovation }\end{array}$ & $\begin{array}{l}\text { Idea of product concept or technology orig- } \\
\text { inated in a developing country }\end{array}$ & $\begin{array}{l}\text { Main locus of product development } \\
\text { an R\&D unit in a developing coun- } \\
\text { try }\end{array}$ & $\begin{array}{l}\text { Product designed for and primarily target- } \\
\text { ing the market of a developing country }\end{array}$ \\
\hline $\begin{array}{l}\text { Determinants of a } \\
\text { Reverse Innovation }\end{array}$ & $\begin{array}{l}\text { Product subsequently developed, launched, } \\
\text { or introduced in an advanced country }\end{array}$ & $\begin{array}{l}\text { Product subsequently launched or } \\
\text { introduced in an advanced country }\end{array}$ & $\begin{array}{l}\text { Product subsequently introduced in an ad- } \\
\text { vanced country }\end{array}$ \\
\hline Shorthand Notation & DAxx or DxAx or DxxA & $x D A x$ or $x D x A$ & $\mathrm{xxDA}$ \\
\hline
\end{tabular}

Table 3. Global innovation flows, with reverse innovation flows in the strong and the weak sense.

\begin{tabular}{lll}
\hline Flow Type & $\begin{array}{l}\text { Reverse Innovation in } \\
\text { the Strong Sense }\end{array}$ & Description \\
\hline ADDA & $\begin{array}{l}\text { Developing Country } \\
\text { Spillover }\end{array}$ & $\begin{array}{l}\text { Products conceived in advanced countries, developed and initially commercialized in developing countries, } \\
\text { and then commercialized in advanced countries }\end{array}$ \\
DADA & $\begin{array}{l}\text { Double Reverse Innova- } \\
\text { tion }\end{array}$ & $\begin{array}{l}\text { Products conceived in developing countries, developed in advanced countries, commercialized first in devel- } \\
\text { oping countries, and then commercialized in advanced countries }\end{array}$ \\
DDAD & $\begin{array}{l}\text { Advanced Country- } \\
\text { Targeted Innovation }\end{array}$ & $\begin{array}{l}\text { Products conceived and developed in developing countries, commercialized first in advanced countries, and } \\
\text { then commercialized in developing countries }\end{array}$ \\
DDAA & $\begin{array}{l}\text { Developing Country In- } \\
\text { novation }\end{array}$ & $\begin{array}{l}\text { Products conceived and developed in developing countries, and commercialized in advanced countries } \\
\text { DDDA }\end{array}$ \\
Reversed PLC & Products conceived and developed in developing countries, and commercialized in advanced countries \\
\hline Flow Type & $\begin{array}{l}\text { Reverse Innovation in } \\
\text { the Weak Sense }\end{array}$ & Description \\
\hline
\end{tabular}


AADA Spillback Innovation

ADAA Cost/Capacity Innovation

ADAD Reverse Spillover

DAAA Front-End Reverse Innovation Inspired PLC
DAAD Developing Country-

Products conceived and developed in advanced countries and specifically targeting developing markets, but eventually commercialized also in advanced countries

Products conceived in advanced countries, developed in developing countries, and commercialized in advanced countries

Products conceived in advanced countries, developed in developing countries, initially commercialized in advanced countries, and then commercialized in developing countries

Products conceived in developing countries, but developed and commercialized in advanced countries

Products conceived in developing countries, developed and commercialized in advanced countries, and then sold in developing countries

\section{Flow Type $\begin{aligned} & \text { Traditional Global In- } \\ & \text { novation Flows }\end{aligned}$}

AAAA Advanced Country-Only Products conceived, developed, and commercialized in advanced countries Innovation

AAAD Vernon's Product Life Cycle

AADD Developing CountryTargeted Innovation

ADDD Advanced CountryInspired Innovation

DADD Advanced CountryBased Localization

DDDD Developing CountryOnly Innovation
Products conceived, developed, and initially sold in advanced countries, and then sold in developing countries

Products conceived and developed in advanced countries, but commercialized in developing countries

Products conceived in advanced countries, but developed and commercialized in developing countries

Products conceived in developing countries, developed in advanced countries, and commercialized in developing countries

Products conceived, developed, and commercialized in developing countries 
Table 4. Examples of global innovation flows.

\begin{tabular}{|c|c|c|c|c|c|c|c|}
\hline $\begin{array}{l}\text { Flow } \\
\text { Type }\end{array}$ & $\begin{array}{l}\text { Type of } \\
\text { Innovation }\end{array}$ & Product(s) Innovated & Company & $\begin{array}{l}\text { Location of } \\
\text { Phase } 1\end{array}$ & $\begin{array}{l}\text { Location of } \\
\text { Phase } 2\end{array}$ & $\begin{array}{l}\text { Location of } \\
\text { Phase } 3\end{array}$ & $\begin{array}{l}\text { Location of } \\
\text { Phase } 4 *\end{array}$ \\
\hline \multirow[t]{2}{*}{ ADDA } & Strong RI & Nokia mass-market entry phones & Nokia & Finland & China & China & Europe \\
\hline & & LifeStraw & Vestergaard & Denmark & Vietnam & Africa/Asia & Europe/USA \\
\hline \multirow[t]{2}{*}{ DADA } & Strong RI & Room terminal, controllers & Carel & China & Italy & China & Europe \\
\hline & & Flexible-fuel vehicle Fiat 147 & Fiat & Brazil & Italy & Brazil & Europe \\
\hline \multirow[t]{2}{*}{ DDAD } & Strong RI & Business One Suite & SAP & China & China & USA/Europe & China/etc. \\
\hline & & Some Dorel baby strollers & Goodbaby & China & China & USA & Latin America \\
\hline \multirow[t]{2}{*}{ DDAA } & Strong RI & High-end impact screwdriver & Bosch & Malaysia & Malaysia & Japan & Germany \\
\hline & & Some Maxi-Cosi baby strollers & Goodbaby & China & China & USA/Europe & USA \\
\hline \multirow[t]{3}{*}{ DDDA } & Strong RI & Vicks Honey Cough & $P \& G$ & Venezuela & Venezuela & Mexico & USA/Europe \\
\hline & & Electrocardiogram (Mac400) & $G E$ & India & India & India & USA \\
\hline & & Several mobile phones & Huawei & China & China & China & USA \\
\hline \multirow[t]{2}{*}{ AADA } & Weak RI & Milk in a pouch & Parmalat & Italy & Italy & Colombia & Canada \\
\hline & & SQFlex & Grundfos & Denmark & Denmark & Africa/Asia & Australia/US \\
\hline ADAA & Weak RI & High-end TV Set-Top Box & STMicroelectronics & France & India & USA & USA \\
\hline \multirow[t]{3}{*}{ ADAD } & Weak RI & Hana In-Memory Apps & $S A P$ & Germany & China/India & USA/Europe & China/India \\
\hline & & FiveFingers shoes & Vibram & Italy & China & USA/Europe & China \\
\hline & & ADMOSS & Siemens & Germany & India & Germany & Philippines etc. \\
\hline DAAA & Weak RI & Compound targets & Wuxi AppTech & China & USA & USA & Europe \\
\hline DAAD & Weak RI & Oncovin & Eli Lilly & Madagascar & USA & USA & Africa \\
\hline AAAA & No RI & Imvamune & Bavarian Nordic & Germany & Germany & USA & Canada \\
\hline AAAD & No RI & Santana & Volkswagen & Germany & Germany & Germany & China \\
\hline AADD & No RI & Lifelink & Grundfos & Denmark & Denmark & Kenya & Africa \\
\hline \multirow[t]{2}{*}{ ADDD } & No RI & Metropolis (DS9) & $P S A$ & France & China & China & China \\
\hline & & MPEG- 1 based VCD & Wanyan & Japan/USA & China & China & Thailand etc. \\
\hline \multirow[t]{2}{*}{ DADD } & No RI & Nicosan & Xechem & Nigeria & USA & Nigeria & Africa \\
\hline & & Tojoy & $J A C$ & China & Italy & China & Egypt/Syria \\
\hline DDDD & No RI & Hippo Roller & Imvubu Projects & South Africa & South Africa & South Africa & Africa \\
\hline
\end{tabular}

\footnotetext{
* = primary target country (among possibly many) in phase 4
} 